\section{Qualitative determination of histamine in canned yellowfin tuna (Thunnus albacares) marketed in Sardinia (Italy) by rapid screening methods}

\author{
Luigi Crobu, ${ }^{1}$ Alessandro Graziano \\ Mudadu, ${ }^{2}$ Rita Melillo, ${ }^{2}$ \\ Giovanni Luigi Pais, ${ }^{1}$ Domenico Meloni ${ }^{1}$ \\ ${ }^{1}$ Department of Veterinary Medicine, \\ University of Sassari; ${ }^{2}$ Veterinary Public \\ Health Institute of Sardinia, Sassari, \\ Italy
}

\begin{abstract}
Histamine is produced by the bacterial decarboxylation of histidine, an ammino acid present in large amount especially in scombroid fish such as tuna. Fish containing high levels of histamine have been associated with many instances of "scombroid poisoning". Since histamine is heat resistant, its presence has been used as an indicator of the good manufacturing practice and of the preservation state of canned tuna. In this study we have applied a rapid screening method to determine the presence of histamine in canned tuna marketed in Sardinia (Italy). A total of 165 samples of canned tuna were screened for the qualitative determination of histamine by HistaSure $^{\mathrm{TM}}$ Fish Rapid Test. The results were consistently in agreement with the food safety criteria $(<100 \mathrm{mg} / \mathrm{kg}$ of histamine) laid down in EC Regulation 2073/2005 (as amended). The HistaSure ${ }^{\mathrm{TM}}$ kit was confirmed as a rapid screening method for the presence of histamine in canned tuna.
\end{abstract}

\section{Introduction}

Histamine is a product of decomposition of the ammino-acid histidine caused by the growth of certain Gram - bacteria (e.g. Morganella, Klebsiella, Proteus, E.coli, Hafnia) in fish tissues of the Scomberesocidae and Scombridae families, e.g., tuna fish, mackerel, sardine, anchovy (Evangelista et al., 2016). The amount of histamine that forms is a function of bacterial species, temperature and time of exposure, and may exceed $1,000 \mathrm{mg} / \mathrm{kg}$. A histamine intake of 70-1000 mg per single meal may be associated with many instances of a major health problem referred to as "scombroid fish poisoning" (Altieri et al., 2016; Nei et al., 2017). The time of onset of this poisoning ranges from several minutes to 3 $\mathrm{h}$ after ingestion of fish containing high levels of histamine (Silva et al., 2011). Several histamine poisoning outbreaks have been reported in many countries over the years, and it is one of the most prevalent forms of seafood-borne disease throughout the world (Silva et al., 2011; Khan et al., 2017). The "scombroid fish poisoning" generally appears in a slight form with a variety of symptoms including rash, urticaria, nausea, vomiting, diarrhea, flushing, tingling and itching of the skin and evolves in about $8 \mathrm{~h}$ but may cause death with the amount of histamine ingested and the individual's sensitivity to histamine (Silva et al., 2011; Khan et al., 2017). Many incidents go unreported because of the mildness of the disease, lack of required reporting and misdiagnosis (Silva et al., 2011). Histamine was the main biocontaminant reported by the Rapid Alert System for Food and Feed (RASFF) in the European Union in 2019 (MinSal, 2020). In this period, 25 notifications were related to fish and products thereof mainly from Vietnam (9 notifications) and France (5 notifications). The presence of histamine in fish and fish products has been used as an indicator of the good manufacturing practice and of the preservation state of seafood, for instance canned fish. Incorrect storing conditions induce production and accumulation of histamine even at temperatures as low as $5^{\circ} \mathrm{C}$. Koohdar et al. (2011) highlighted several food safety issues in the usual fishing method in the Oman Sea and post-fishing procedures used in the local tuna canning industry: $42.2 \%$ of the frozen tuna samples showed more than $50 \mathrm{ppm}$ amount of histamine. Moreover, quality loss and histamine accumulation often occur after poor quality frozen fish is thawed and kept for long periods of time at room temperature before further processing (Tsai et al., 2005). At the same time, defective handling techniques of high-quality fish during processing results in the presence of toxic levels of histamine in canned products (Zarei et al., 2011; Mercogliano and Santonicola, 2019). Since histamine is heat resistant, once produced it cannot be destroyed in canned fish products (Khan et al., 2017). Scombrotoxic fish usually contains levels of histamine more than $200 \mathrm{mg} / \mathrm{kg}$ but such fish may be randomly dispersed within a lot. For large fish, histamine is found at variable levels even within individual fish. Sensory evaluation of the fish is not sufficient to detect the absence or presence of histamine; therefore, chemical testing is required (Silva et al., 2011). Quality control measures designed to minimize the occurrence of scombrotoxic fish require the determination of histamine levels in the range of approximately 10 to $200 \mathrm{mg} / \mathrm{kg}$ (Köse et al.,
Correspondence: Domenico Meloni, Department of Veterinary Medicine, University of Sassari, Via Vienna 2, 07100, Sassari, Italy.

Tel.: +39.079.229570 - Fax: +39.079.229458

E-mail:dmeloni@uniss.it

Key words: Histamine; canned tuna; food safety; screening; rapid methods.

Conflict of interest: The authors declare no conflict of interest.

Contributions: The authors contributed equally.

Funding: This work was funded by FFABR 2017-Fondo per il finanziamento delle attività base di ricerca destinato a finanziare le attività base di ricerca dei professori di seconda fascia e dei ricercatori in servizio a tempo pieno (Legge 11 dicembre 2016 n. 232 (gu n.297 del 21-12-2016 - suppl. ordinario n. 57). CUP J81I17000310001.

Ethics approval: This research was conducted in accordance with all relevant guidelines and procedures.

Received for publication: 2 October 2020.

Revision received: 25 January 2021

Accepted for publication: 22 March 2021.

This work is licensed under a Creative Commons Attribution-NonCommercial 4.0 International License (CC BY-NC 4.0).

(C) Copyright: the Author(s), 2021

Licensee PAGEPress, Italy

Italian Journal of Food Safety 2021; 10:9379

doi:10.4081/ijfs.2021.9379

2011). Good quality fish contains less than $10 \mathrm{mg} / \mathrm{kg}$ histamine, a level of $30 \mathrm{mg} / \mathrm{kg}$ indicates significant deterioration and 50 $\mathrm{mg} / \mathrm{kg}$ is evidence of definite decomposition. In the United States of America (USA), the defect action level (DAL), the level at which regulatory actions are taken by Food and Drug Administration (FDA) for histamine, is $50 \mathrm{mg} / \mathrm{kg}$ (Bajpai et al., 2020). In the EU, the EC Regulation 2073/2005 (as amended) specified the contents of histamine in fish placed on the market during their shelf-life. In fishery products from fish species associated with a high amount of histidine (particularly fish species of the families: Scombridae, Clupeidae, Engraulidae, Coryfenidae, Pomatomidae, Scombresocidae), single samples may be taken at retail level. In the nine units comprising the sample, two units may have a value of more than 100 $\mathrm{mg} / \mathrm{kg}$ but less than $200 \mathrm{mg} / \mathrm{kg}$. No sample unit may have a value $\geq 200 \mathrm{mg} / \mathrm{kg}$. In fishery products which have undergone enzyme maturation treatment in brine, 
manufactured from fish species associated with a high amount of histidine and belonging to the above-mentioned families, out of the nine units comprising the sample, two units may have a value of more than 200 $\mathrm{mg} / \mathrm{kg}$ but less than $400 \mathrm{mg} / \mathrm{kg}$. No sample unit may have a value $\geq 400 \mathrm{mg} / \mathrm{kg}$. On the other hand, the EC Regulation 1019/2013 specified the contents of histamine in fish sauce produced by fermentation of fishery products placed on the market during their shelf-life. The single sample taken at retail level may have a value $<400 \mathrm{mg} / \mathrm{kg}$. Due to the high-resolution power, sensitivity, flexibility, and reproducibility amongst all, HPLC based on liquid chromatography is the analytical reference method in the EU for the analysis of histamine (Nadeem et al., 2015). A relatively large number of alternative analytical methods have been reported in the literature for the determination of histamine in such products (Eva et al., 2013; Sarzamin et al., 2017; Tibor et al., 2017; Lili et al., 2017; Khan et al., 2017; Surya et al., 2019). Nevertheless, the major drawback of most of these methods is that they are costly and timeconsuming techniques and required high technical skills. Therefore, it is essential to develop sufficiently sensitive and rapid costeffective methods to detect histamine residues for food diagnosis (Rogers and Staruszkiewicz, 2000). An interest in "portable" procedures for field analysis capable of rapid screening fishery products dockside has led to the development of commercial test kits proposed for Hazard Analysis Critical Control Points (HACCP) plan applications (Köse et al., 2011). The main aim of the work presented herein was the application of one of the simplest and rapid commercial screening procedures (HistaSure $^{\text {TM }}$ Fish Rapid Test, LDN, Nordhorn, Germany) for the qualitative detection of histamine in canned yellowfin tuna (Thunnus Albacares) samples marketed in Sardinia (Italy). The HistaSure ${ }^{\text {TM }}$ Fish Rapid Test (LDN) is a dipstick test intended for the rapid screening of histamine in different scombroid fish types such as tuna, mahi mahi, sardines and for the screening of histamine in fishmeal. The compliance of the Common Organisation of the Markets of Fishery and Aquaculture Products (CMO) rules on the labelling and marketing for preserved tuna (EEC Regulation 1536/92 and EU Regulation 1379/2013) was also evaluated.

\section{Materials and methods}

\section{Collection of the samples and evalu- ation of European Union labelling}

From December 2018 to October 2019, a total of 165 samples belonging to the five main Italian canned yellowfin tuna (Thunnus albacares) brands (A, B, C, D, E) were collected from large retail stores located in the town of Sassari (Italy). Three cans x $80 \mathrm{~g}$ of yellowfin tuna (Thunnus albacares) in water per month per each brand were included in the study. The samples were transported to the laboratories of the Department of Veterinary Medicine at the University of Sassari (Italy) and were analysed within $24 \mathrm{~h}$ of collection. The labels of the five brands were visually evaluated to assess the compliance of the Common Organisation of the Markets of Fishery and Aquaculture Products (CMO) rules on the labelling and marketing for preserved tuna (EEC Regulation 1536/92 and EU Regulation 1379/2013. The main characteristics of the five canned yellowfin tuna (Thunnus albacares) labels are reported in Table 1.

\section{Determination of histamine}

The presence of histamine in all the samples was carried out by HistaSure ${ }^{\mathrm{TM}}$ Fish Rapid Test (LDN). The official protocol provided a cut-off set at $50 \mathrm{ppm}$ Histamine (https://ldn.de/wp-content/uploads/fc-1-

3200-en-v13.0_wZ.pdf). In case of needs for cut-off adjustments, the manufacturer should be contacted directly to get customized solutions. In order to obtain results easily compared with the food safety criteria laid down in EC Regulation 2073/2005 (as amended), we have decided to set the cut-off to $100 \mathrm{mg} / \mathrm{kg}$ histamine and contact the manufacturer for the proper instructions. The cut-off was then adjusted during the sample extraction step by varying the amount of distilled water in which the fish sample was homogenized. All reagents were kept at room temperature $\left(18-25^{\circ} \mathrm{C}\right)$ prior to use. The preliminary preparation of the samples for the test procedure was carried out according to the AOAC Official Method 937.07 for canned fish and other canned marine products (AOAC, 2000): the entire content of the can (meat and liquid) was placed in a blender (Koenich, Munich, Germany) and blended until homogenous. Ten $g$ of each prepared canned tuna sample were weighted, added to $490 \mathrm{ml}$ distilled water, and homogenized for 1-2 minutes in a blender (Koenich). The homogenate was then filtered through folded filter paper. An aliquot of $100 \mu \mathrm{l}$ of the filtered homogenate was pipetted into the Acylation Buffer Vials and mixed vigorously by hand. The vials were incubated for 5 minutes at room temperature. $100 \mu$ of the acylated samples were pipetted into the Running Buffer Vials and mixed gently. The Lateral Flow Device was added to the Running Buffer Vials and incubated for 5 minutes. At the end of incubation, the Lateral Flow Device was removed from the Running Buffer Vial and the results visually read within 5 minutes. A negative control represented by $100 \mu \mathrm{l}$ of distilled water was included in each sampling session. The intensity of the test line (amount of immunogold labelled antibody bound to the solid phase histamine and inversely proportional to the histamine concentration in the sample) was compared to the intensity of the control line (upper line) which was always visible. This was the confirmation that the test had operated correctly.

\section{Results and discussion}

The visual inspection of the five canned yellowfin tuna (Thunnus albacares) labels (Table 1) enabled us to highlight that all the brands followed the CMO-related Regulations rules on mandatory information for the marketing of preserved tuna (EEC Regulation 1536/92 and EU Regulation 1379/2013). In addition to the mandatory information, clear and unambiguous voluntary information were provided by all the Food Business Operators (FBOs). According to the EEC Regulation 1536/92, the trade description of preserved tuna shall be reserved for products prepared exclusively from fish of one of the following species of the genus Thunnus: Albacore or longfinned tuna (Thunnus alalunga); Yellowfin tuna (Thunnus albacares); Bluefin tuna (Thunnus thynnus); Bigeye tuna (Thunnus obesus) and to the following species of the genus Katsuwonus: Skipjack or stripe-bellied tuna (Katsuwonus pelamis). All the labels reported $T$. albacares as scientific name and yellowfin tuna as commercial designation. The fishing gear category was not reported in labels A, B and D. Purse seine was reported as fishing method in labels $\mathrm{C}$ and E. Yellowfin tuna caught by large-scale purse seiners cannot immediately be collected after entrapping and they remain inside the water for a while with significant duration before being transferred on board to be cooled and subsequently frozen and stored (Koohdar et 
al., 2010). If these delays are extended, some post-mortem decomposition and accumulation of histamine can occur in these fishes (Yoshinaga and Frank, 1982). Most of the labels always reported two or more fishing areas, most of which were in the Indian and Pacific Oceans. No catch area was reported on the labels of the brand B. The declared conditions for storage and use varied considerably between the five companies: label A recommended to consume the entire content once opened the can. Labels $\mathrm{C}$ and $\mathrm{D}$ suggest refrigeration of the opened cans and consumption within 1 day. Labels B and E reported only to store the cans in a cold and dry place. The presence of histamine was always $<100 \mathrm{mg} / \mathrm{kg}$ in all the 165 samples These results were consistently in agreement with the food safety criteria laid down in EC Regulation 2073/2005 (as amended) for fishery products from fish species associated with a high amount of histidine. Previous studies carried out in canned tuna marketed in several countries showed histamine levels always $<100$ $\mathrm{mg} / \mathrm{kg}$ : China $(0.02,19.79,7.46$, and 1.40 $\mathrm{mg} / \mathrm{kg})$, Republic of Korea $(0.10 \mathrm{mg} / \mathrm{kg})$, Taiwan (45.0 $\mathrm{mg} / \mathrm{kg})$, Malaysia (3.20 $\mathrm{mg} / \mathrm{kg})$, Iran (77.86 mg/kg), Oman (3.18 mg $\mathrm{kg})$, Turkey $(10.97,1.38$, and $27.05 \mathrm{mg} / \mathrm{kg})$ and Brazil (9.30 and $4.41 \mathrm{mg} / \mathrm{kg}$ ), (Rahmani et al., 2018). As reported by Mercogliano and Santonicola (2019), high levels of histamine in canned tuna can be also related to the treatment and presentation: grated canned tuna in oil and with tomatoes showed higher levels (9.57 and $17.00 \mathrm{mg} / \mathrm{kg}$, respectively) than grated canned tuna in water and salt $(0.36 \mathrm{mg} / \mathrm{kg})$ and solid fish $(0.74 \mathrm{mg} / \mathrm{kg})$.

\section{Conclusions}

Histamine testing is a possible control strategy that can be used by FBOs to control histamine health hazard in the complex and fragmented food service supply chain, where the main problems are related to the respect of EU framework in terms of food safety and traceability. Restaurants, company canteens, and cafeterias are the main reported sources of "scombroid fish poisoning" outbreaks (Mercogliano and Santonicola, 2019). The cooking treatment before canning can eliminate both histamine-producing bacteria and their enzymes. Since histamine is heat resistant, once produced, it cannot be destroyed in canned final products because it was present before the heating process started (Khan et al., 2017; Visciano, Schirone and Paparella, 2020). Tuna cans used as ingredient (tuna salad and tuna sandwiches) may be opened hours or week before the preparation or consumption, with likely post-processing contamination and histamine production (Colombo et al., 2018). Although all the companies included in our study were in compliance with the CMO-related Regulations rules on mandatory and voluntary information for the marketing of preserved tuna (EEC Regulation 1536/92 and EU Regulation 1379/2013), the declared conditions for storage and use reported by the companies B and $\mathrm{E}$ (only the storage of the cans in a cold and dry place was recommended) should be

Table 1. Main characteristics of the five canned yellowfin tuna (Thunnus albacares) brands included in the study.

\begin{tabular}{|c|c|c|c|c|c|}
\hline Brand & A & B & C & D & $\mathbf{E}$ \\
\hline Name of the food & Natural tuna & Natural tuna & Natural tuna & Natural tuna & Natural tuna \\
\hline Net weight & $80 \mathrm{~g}$ & $80 \mathrm{~g}$ & $80 \mathrm{~g}$ & $80 \mathrm{~g}$ & $80 \mathrm{~g}$ \\
\hline Drained net weight & $56 \mathrm{~g}$ & $56 \mathrm{~g}$ & $56 g$ & $56 \mathrm{~g}$ & $56 \mathrm{~g}$ \\
\hline Food Business Operator (business name and address & Yes & Yes & Yes & Yes & Yes \\
\hline Identification mark & Yes & Yes & Yes & Yes & Yes \\
\hline Country of origin & Yes & Yes & Yes & Yes & Yes \\
\hline Tuna species & T. albacares & T. albacares & T. albacares & T. albacares & T. albacares \\
\hline Catch (FA0) area & $34-47-51-71-77-87$ & n.r. & $34-41-47-51-57-71-77-81-87$ & $51-71$ & $34-51-71$ \\
\hline Fishing system & n.r. & n.r. & Purse seine & n.r. & Purse seine \\
\hline List of ingredients & $\begin{array}{c}\text { Tuna, water, } \\
\text { salt } \\
\text { natural celery } \\
\text { and onion flavoring }\end{array}$ & $\begin{array}{l}\text { Tuna }(85 \%) \text {, } \\
\text { water, salt, }\end{array}$ & $\begin{array}{c}\text { Tuna, water, salt, } \\
\text { yeast extract }\end{array}$ & $\begin{array}{c}\text { Tuna, water, salt, } \\
\text { natural flavors }\end{array}$ & Tuna, water, salt \\
\hline \multicolumn{6}{|l|}{ Nutrition declaration } \\
\hline Energy* & $97 \mathrm{kcal}$ & $93 \mathrm{kcal}$ & $84 \mathrm{kcal}$ & $100 \mathrm{kcal}$ & $100 \mathrm{kcal}$ \\
\hline Fat* & $1.0 \mathrm{~g}$ & $0.5 \mathrm{~g}$ & $0.6 \mathrm{~g}$ & $0.9 \mathrm{~g}$ & $0.9 \mathrm{~g}$ \\
\hline Saturated fatty acids* & $0.3 \mathrm{~g}$ & $0.2 \mathrm{~g}$ & $0.1 \mathrm{~g}$ & $0.2 g$ & $0.2 \mathrm{~g}$ \\
\hline Carbohydrates* & $0 \mathrm{~g}$ & $0 \mathrm{~g}$ & $0 \mathrm{~g}$ & $0 \mathrm{~g}$ & $0 \mathrm{~g}$ \\
\hline Sugars* & $0 \mathrm{~g}$ & $0 \mathrm{~g}$ & $0 \mathrm{~g}$ & $0 \mathrm{~g}$ & $0 \mathrm{~g}$ \\
\hline Proteins* & $21 g$ & $22 \mathrm{~g}$ & $20 \mathrm{~g}$ & $23 g$ & $23 g$ \\
\hline Salt* & $1.3 \mathrm{~g}$ & $1.1 \mathrm{~g}$ & $1.5 \mathrm{~g}$ & $1.3 \mathrm{~g}$ & $1.3 \mathrm{~g}$ \\
\hline Phosphorus & n.r.** & n.r. & $162 \mathrm{mg}$ & n.r. & n.r. \\
\hline Iodine & n.r. & n.r. & $50 \mu g$ & n.r. & n.r. \\
\hline Vitamin B12 & n.r. & n.r. & $2.0 \mu g$ & n.r. & n.r. \\
\hline Best before date/use by date & Yes & Yes & Yes & Yes & Yes \\
\hline Storage conditions & $\begin{array}{l}\text { eep in a cold and dry place. } \\
\text { It is recommended to } \\
\text { consume it in its } \\
\text { tirety once opened the can }\end{array}$ & $\begin{array}{l}\text { Keep in a cold and } \\
\text { dry place }\end{array}$ & $\begin{array}{l}\text { Once opened the can, } \\
\text { keep refrigerated and } \\
\text { consume within } 1 \text { day }\end{array}$ & $\begin{array}{l}\text { Keep in a cold and } \\
\text { dry place. } \\
\text { After opening, } \\
\text { keep refrigerated and } \\
\text { consume within 1 day }\end{array}$ & $\begin{array}{l}\text { Keep in a cold and } \\
\text { dry place. }\end{array}$ \\
\hline Bar code & Yes & Yes & Yes & Yes & Yes \\
\hline
\end{tabular}

*per $100 \mathrm{~g}$ of canned tuna; ** not reported. 
improved. Since labels help consumers to consciously choose a product according to desirable characteristics (Brom, 2000), FBOs must be appropriately trained on the importance of effective information about the storage and consumption on the labels of their products (Esposito and Meloni, 2017). Commercial test kits based on immunoassay methods for histamine analyses are very popular because of their user-friendliness and reduced time requirements compared to those of traditional analytical techniques (Köse et al., 2011). These simple detection technologies used as screening tests must be reinforced by confirmatory methods if positive results are achieved (Visciano, Schirone and Paparella, 2020). However, previous studies (Köse et al., 2011) reported good agreement of the results obtained by HistaSure $^{\mathrm{TM}}$ Fish Rapid Test (LDN) with HPLC results, highlighting that this qualitative kit is suitable for either HACCP monitoring histamine in seafood processing plants or regulatory purposes that uses FDA as well as EU upper permitted limits. HistaSure $^{\mathrm{TM}}$ Fish Rapid Test (LDN) offered great advantages and can be easily used as screening kit in HACCP applications.

\section{References}

Altieri I, Semeraro A, Scalise F, Calderari I, Stacchini P, 2016. European official control of food: Determination of histamine in fish products by a HPLCUV-DAD method. Food Chem, 211: 694-9.

AOAC, 2000. AOAC Official Method 937.07 Fish and Marine Products Treatment and Preparation of Sample Procedure. Official Methods of Analysis of AOAC International (17th ed.), Gaithersburg, MD, Section 35.1.01.

Bajpai VK, Oh C, Khan I, Haldorai Y, Gandhi S, Lee H, Song X, Kim M, Upadhyay A, Chen L, Huh YS, Han YK, Shukla S, 2020. Fluorescent immunoliposomal nanovesicles for rapid multi-well immuno-biosensing of histamine in fish samples. Chemosphere 243: 125404.

Brom FWA, 2000. Food, consumer concerns, and trust: food ethics for a globalizing market. J Agric Environ Ethics 12: 127-39.

Colombo FM, Cattaneo P, Confalonieri E, Bernardi C, 2018. Histamine food poisonings: A systematic review and meta-analysis. Crit Rev Food Sci Nutr 58: 1131-51.

Esposito G, Meloni D, 2017. A case-study on compliance to the EU new requirements for the labelling of fisheries and aquaculture products reveals difficulties in implementing Regulation (EU) n.1379/2013 in some large-scale retail stores in Sardinia (Italy). Regional Studies in Marine Sci, 9: 56-61

European Council, 1992. Council Regulation (EEC) No 1536/92 of 9 June 1992 laying down common marketing standards for preserved tuna and bonito. Official Journal of the European Communities, L 163/1-4.

European Commission, 2005. Commission Regulation (EC) No 2073/2005 of 15 November 2005 on microbiological criteria for foodstuffs Official Journal of the European Union, L 338/1-26

European Union (2013). European Union (EU) Regulation No $1379 / 2013$ of the European Parliament and of the Council of 11 December 2013 on the common organisation of the markets in fishery and aquaculture products, amending Council Regulations (EC) No 1184/2006 and (EC) No 1224/2009 and repealing Council Regulation (EC) No 104/2000. Official Journal of the European Union, L 354/1-21.

Eva LR, Alberto A, Jesus HB, Jesus MP, 2013. NMR study of histidine metabolism during alcoholic and malolactic fermentation of wine and their influence on histamine production. J Agricult Food Chem 61: 9464-9.

Evangelista WP, Silva TM, Guidi LR, Tette PAS, Byrro RMD, Santiago-Silva P, Fernandes C, Gloria MBA, 2016. Quality assurance of histamine analysis in fresh and canned fish. Food Chem 211: 100-6.

Labor Diagnostika Nord (LDN), 2020. Instructions for use HistaSure TM Fish Rapid Test. Available at: https://ldn.de/wp-content/uploads/fc-l3200-en-v13.0 wz.pdf. Accessed on September, 22nd 2020.

Lili H, Zhongqi X, Takeshi HK, Li S, 2017. Simultaneous determination of aliphatic, aromatic and heterocyclic biogenic amines without derivatization by capillary electrophoresis and application in beer analysis. J of Chromatography A 1482: 109-14.

Mercogliano R, Santonicola S, 2019. Scombroid fish poisoning: Factors influencing the production of histamine in tuna supply chain. A review. LWT Food Sci Tech 114: 108374.

Ministero della Salute, Direzione Generale per l'Igiene e la Sicurezza degli Alimenti e la Nutrizione (2020). RASFF Rapid Alert System for Food and Feed Sistema di Allerta Rapido per Alimenti e Mangimi. Relazione Annuale 2019. http://www.salute.gov.it/imgs/C_17_pub blicazioni 2914 allegato.pdf. Accessed 28.09.2020.

Nadeem M, Naveed T, Rehman F, Xu Z, 2019. Determination of histamine in fish without derivatization by indirect reverse phase-HPLC method. Microchem J 144: 209-14.

Nei D, Nakamura N, Ishihara K, Kimura M, Satomi M, 2017. A rapid screening of histamine concentration in fish fillet by direct analysis in real time mass spectrometry (DART-MS). Food Control 75: 181-6.

Rahmani J, Miri A, Mohseni-Bandpei A, Fakhri Y, Bjørklund G, Keramati H, Moradi B, Amanidaz N, Shariatifar N, Khaneghah AM, 2018. Contamination and prevalence of histamine in canned tuna from Iran: A systematic review, meta-analysis, and health risk assessment. J Food Prot 8: 2019-27.

Rogers PL, Staruszkiewicz WF, 2000. Histamine Test Kit Comparison. J Aquat Food Product Tech 9: 5-17.

Sarzamin K, Leonardo SAC, Monica SV, Eric CR, Ricardo QA, 2017. Determination of histamine in tuna fish by photoluminescence sensing using thioglycolic acid modified CdTe quantum dots and cationic solid phase extraction. J Luminescence, 182: 71-8.

Silva TM, Sabaini PS, Evangelista WP, Gloria MBA, 2011. Occurrence of histamine in Brazilian fresh and canned tuna. Food Control 22: 323-7.

Surya ST, Sivaraman B, Alamelu V, Priyatharshini A, Arisekar U, Sundhar S, 2019. Rapid Methods for Histamine Detection in Fishery Products. Int J Curr Microbiol Appl Sci 8: 2035-46

Tibor J, Davor V, Jasenka G, Gajdos K, Lara M, Sanja V, Mile I, 2017. Determination of histamine in fish by Surface Enhanced Raman Spectroscopy using silver colloid SERS substrates. Food Chem 224: 4854.

Tsai YH, Kung HF, Lee TM, Chen HC, Chou SC, Wei CI, Hwang DF, 2005. Determination of histamine in canned mackerel implicated in a food borne poisoning. Food Control 16: 579-85.

Visciano P, Schirone M, Paparella A, 2020. An overview of histamine and other biogenic amines in fish and fish products. Foods 9: 1-15.

Yoshinaga DH and Frank HA, 1982. Histamine-Producing bacteria in decomposing skipjack tuna (Katsuwonus pelamis). Appl Environ Microbiol 44: 447-52.

Khan S, Carneiro LSA, Vianna MS, Romani EC, Aucelio RQ, 2017. Determination of histamine in tuna fish by photoluminescence sensing using 
thioglycolicacid modified CdTe quantum dots and cationic solid phase extraction. J Luminescence 182: 71-8.

Koohdar VA, Razavilar V, Motalebi AA, Mosakhani F, Valinassab T, 2010. Isolation and Identification of Histamine-forming bacteria in frozen
Skipjack tuna (Katsuwonus pelamis). Iranian J Fish Sci 10: 678-88.

Köse S, Kaklıkkaya N, Koral S, Tufan B, Buruk KC, Aydın F, 2011. Commercial test kits and the determination of histamine in traditional (ethnic) fish products-evaluation against an EU accepted HPLC method. Food Chem 125: 1490-7.

Zarei M, Najafzadeh H, Enayati A, Pashmforoush M, 2011. Biogenic amines content of canned tuna fish marketed in Iran. Am Euras J Toxicol Sci 3: 190-3. 